\title{
Ameliorative Effect of Alpha Lipoic Acid on Endometriosis: An Experimental Model in Rats
}

\section{Alfa Lipoik Asidin Endometriozis Üzerindeki lyileştirici Etkisi: Sıçanlarda Deneysel Model}

\author{
๑ Taylan Onat, ๑ Murat Çakır* \\ Yozgat Bozok University Faculty of Medicine, Department of Gynecology and Obstetrics Yozgat, Turkey \\ * Yozgat Bozok University Faculty of Medicine, Department of Physiology, Yozgat, Turkey
}

Abstract

Aim: This study aims to evaluate the effects of alpha lipoic acid (ALA), which is a strong antioxidant, on endometriosis (EMS).

Methods: Thirty sexually-mature, female Wistar albino rats weighing 180-220 grams were separated into three groups: sham $(n=10)$, EMS $(n=10)$ and EMS + ALA $(n=10)$. Blood samples were taken from the rats and were centrifuged and stored at -80 ${ }^{\circ} \mathrm{C}$ before forming the experimental EMS model. ALA at a dose of $50 \mathrm{mg} / \mathrm{kg}$ was orally administered to EMS + ALA group. At the end of this procedure, blood samples were taken again and were centrifuged and stored at $-80{ }^{\circ} \mathrm{C}$. Plasma total antioxidant status (TAS), plasma total oxidant status, oxidative stress (OS) index and cancer antigen 125 were studied from these samples.

Results: There were no differences between the groups in terms of baseline results. According to the second blood test results, all parameters in the sham group and all parameters other than plasma TAS in EMS + ALA group were statistically different than in EMS group $(p<0.05)$. Considering the 1 st and $15^{\text {th }}$ day changes in the parameters of the groups, it was observed that ALA had positive effects.

Conclusion: ALA reduces OS in EMS; thus, may have a positive effect on the severity and stage of the illness and reduce recurrence after treatment.

Keywords: Endometriosis, oxidative stress, alpha lipoic acid
Amaç: Bu çalışma güçlü bir antioksidan olan alfa lipoik asitin (ALA) endometriozis (EMS) üzerine etkilerini değerlendirmeyi amaçlamaktadır.

Yöntemler: Otuz adet, 180-220 gram ağırlığında, seksüel matür, dişi Wistar albino rat üç gruba ayrılmıştır: Sham, EMS grubu ve EMS + ALA grubu. Deneysel EMS modeli oluşturulmadan ratlardan kan örnekleri alındı ve santrifüj edilerek $-80{ }^{\circ} \mathrm{C}^{\prime}$ de saklandı. EMS + ALA grubuna 15 gün, 50 mg/kg dozda, oral yoldan alfa lipoik asit verildi. Bu sürenin sonunda ratlarda tekrar kan örnekleri alındı ve santrifüj edilerek $-80{ }^{\circ} \mathrm{C}^{\prime}$ de saklandı. Bu örneklerden plazma total antioksidan status (TAS), plazma total oksidan status, oksidatif stres (OS) indeks ve kanser antijen 125 çalışıldı.

Bulgular: Grupların başlangıç sonuçları arasında farklılık yoktu. İkinci alınan kan sonuçlarında sham grubu bütün parametrelerde, EMS + ALA grubu ise plazma TAS dışındaki bütün parametrelerde EMS grubundan istatiksel olarak farklıydı $(p<0,05)$. Gruplarda parameterelerin 1.-15. gün değişimine baktığımızda ALA'nın olumlu etkilerini saptadık.

Sonuç: ALA, EMS'de OS'yi azaltarak hastalığın şiddeti ve evresi üzerinde olumlu etki gösterebilir, ayrıca tedavi sonrası nüksleri azaltabilir.

Anahtar Sözcükler: Endometriozis, oksidatif stress, alfa lipoik asit
Address for Correspondence/Yazışma Adresi: Taylan Onat, Yozgat Bozok University Faculty of Medicine, Department of Gynecology and Obstetrics Yozgat, Turkey E-mail: onat.taylan@gmail.com ORCID: orcid.org/0000-0002-8920-1444

Received/Geliş Tarihi: 14 June 2020 Accepted/Kabul Tarihi: 23 August 2020
${ }^{\circ}$ Copyright 2020 by The Medical Bulletin of istanbul Haseki Training and Research Hospital The Medical Bulletin of Haseki published by Galenos Yayınevi. Telif Hakkı 2020 istanbul Haseki Eğitim ve Araştırma Hastanesi Haseki Tıp Bülteni, Galenos Yayınevi tarafından yayınlanmıştır. 


\section{Introduction}

Endometriosis (EMS) is a common estrogen-dependent gynecological disease defined by the presence of endometrial-like glands and stroma outside the uterine cavity. EMS is observed in 10\% of women of reproductive age, and $35-50 \%$ of women with pelvic pain and/or infertility are diagnosed with EMS (1). Considering that EMS diagnosis requires histopathological verification, its frequency might be higher. It negatively affects women's health with its primary symptoms such as chronic pelvic pain, dyspareunia, dysmenorrhea and infertility. Although it mostly settles in the pelvic peritoneum, its involvement in the ovary and rectovaginal septum is considerably frequent. The risk of recurrence after treatment is quite high in the first stage of EMS (2). EMS was first defined in 1,860 but its etiopathogenesis has still not been clarified (3). The most popular theory among the various proposed theories is the theory of retrograde menstruation (Sampson) (4). However, although 90\% of women have retrograde menstruation, the fact that EMS is observed to a lesser extent suggests that additional factors such as inflammatory and immune factors are effective in the development of the disease (5).

Oxidative stress (OS) is oxidant-antioxidant imbalance in favor of the oxidants. Antioxidant system consists of enzymatic (e.g. catalase, superoxide dismutase) and nonenzymatic (e.g. vitamin C and selenium) substances. Recent findings have shown that OS has a key role in the development of EMS and spread of the endometrial tissue $(6,7)$. The idea that OS may trigger inflammation in EMS, which is a chronic inflammatory disease, is gaining currency. OS may also cause inflammation with the changes it causes in endothelial cells (increased permeability and adhesion molecule expression in endothelial cells) (6). It was found that there was a correlation between the severity of EMS and lipid peroxide activity in blood and peritoneal fluid (8). Moreover, another study determined that low GSH peroxidase and high malondialdehyde levels were found in ectopic endometrial tissue (9). In this case, it increases the possibility of using antioxidant agents in the treatment of EMS. Antioxidant agents have been used for EMS treatment in human studies and animal experiments (9-11).

Alpha lipoic acid (ALA) is a powerful antioxidant found naturally inside every cell of the human body. It has an important role in metabolism due to the fact that it is the cofactor for various mitochondrial enzymes (12). Besides its antioxidant properties, ALA helps regenerate other endogenous antioxidants such as GSH (13). Protective effect of ALA has been investigated in experimental ischemia/reperfusion (I/R) injuries $(14,15)$. To the best of our knowledge, there has been no study examining the ameliorative effect of ALA on EMS. This study aims to examine the effects of ALA on EMS in which there are robust findings indicating that OS plays a role in its etiopathogenesis.

\section{Methods}

This study was carried out in the Saki Yenilli Production and Application Laboratory. The study was conducted in accordance with the Animals Research: Reporting of in vivo Experiments (ARRIVE) guidelines after obtaining approval from the Ethics Committee of the same center (no: 01.03.01, date: 06/01/2020). Since the experimental nature of the study, informed consent was not obtained.

Thirty sexually-mature, female Wistar albino rats weighing 180-220 grams were used in this experiment. The rats were monitored for a few days before the first phase of the experiment and were determined to be healthy.

The rats were randomly dived in three groups: sham $(n=10)$, EMS $(n=10)$ and EMS + ALA (EMS + ALA, $n=10)$. A combination of $7 \mathrm{mg} / \mathrm{kg}$ xylazine hydrochloride (Bayer, Turkey) and $50 \mathrm{mg} / \mathrm{kg}$ ketamine hydrochloride (Eczacıbası, Turkey) was intraperitoneally injected for anesthesia. Before starting surgical procedure, approximately $1 \mathrm{~mL}$ of intravenous blood was taken from all rats. These samples were centrifuged at $4,000 \mathrm{rpm}$ for 10 minutes. Serums were stored at $-80{ }^{\circ} \mathrm{C}$ for biochemical evaluation. The rats were put on surgical platform in the supine position. After shaving the abdominal area and cleaning with $10 \%$ povidone-iodine, approximately $2-3 \mathrm{~cm}$ long vertical incision was made. In the sham group, abdomen was closed with a 4/0 Vicryl Rapide Polyglactin 910 suture (Ethicon Inc., Somerville, NJ). The EMS model was formed within the frame of a procedure determined by Uygur et al. (16) in EMS and EMS + ALA groups. Skin closure was done using 4/0 Vicryl Rapide Polyglactin 910 suture. The EMS + ALA group was started ALA (Sigma-Aldrich, Darmstadt, Germany) at a dose of $50 \mathrm{mg} / \mathrm{kg}$ by oral administration using a gavage one day after the procedure, and the treatment was continued for 15 days. At the end of 15 days, second blood samples taken from the rats under anesthesia were centrifuged and stored at $-80^{\circ} \mathrm{C}$.

Plasma total antioxidant status (TAS) measurement was made according to the Erel (17) method using a commercial kit (REL Assay Diagnostics, Gaziantep, Turkey). The basis of the method is the reduction of the dark blue-green ABTS radical into colorless ABTS form through antioxidant substances in the samples. $18 \mu \mathrm{L}$ of plasma was added over $300 \mu \mathrm{L}$ of reactive (acetate buffer $0.4 \mathrm{~mol} / \mathrm{L}$, $\mathrm{pH}=5.8$ ) solution. The measurement was made at $660 \mathrm{~nm}$ wavelength after 30 seconds using a spectrophotometer device (Shimadzu UV-1800, Kyoto, Japan). Then, reactive 
2 (prochromogen ABTS $30 \mathrm{mmol} / \mathrm{L}$ ) solution was added and kept at $37{ }^{\circ} \mathrm{C}$ for 5 minutes and spectrophotometric measurements were made at $660 \mathrm{~nm}$. For the calculation of the measurements, the absorbance change was calculated by deducting the first measurement value from the second measurement value. Then, the calculation was made according to the formula using the absorbance changes: $\mathrm{TAS}=\Delta$ Abs $\mathrm{H}_{2} \mathrm{O}-\Delta$ Abs sample $/ \Delta$ Abs $\mathrm{H}_{2} \mathrm{O}-\Delta$ Abs standard. The results were presented as mmol Trolox equivalent/L.

Plasma plasma total oxidant (TOS) measurement was made according to the Erel (18) method using the commercial kit (REL Assay Diagnostics, Gaziantep, Turkey). Oxidants in the sample oxidize the ferrous ion-chelator complex into ferric ions. Color intensity is related to the oxidant molecule amount. The measurement was made in line with the measurement protocol included in the kit. $45 \mu \mathrm{L}$ plasma was added over $300 \mu \mathrm{L}$ tampon solution

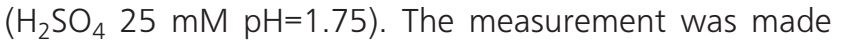
at $530 \mathrm{~nm}$ wavelength with spectrophotometer after 30 seconds. Then, $15 \mu \mathrm{L}$ substrate solution was added and waited for 5 minutes at $37^{\circ} \mathrm{C}$, and the measurement was repeated with the spectrophotometer device at $530 \mathrm{~nm}$ wavelength. For the calculation of the measurements, the absorbance change was calculated by deducting the first measurement value from the second measurement value. Calculations were made according to formula included in the kit: $T O S=\Delta$ Abs sample/ $\Delta$ Abs standard $\times 10$. The results were presented as $\mu \mathrm{mol} \mathrm{H}_{2} \mathrm{O}_{2}$ equivalent/L.

Oxidative stress index (OSI) was calculated using TAS and TOS results according to the following formula (19): OSI (arbitrary unit $)=\operatorname{TOS}\left(\mu \mathrm{mol} \mathrm{H}_{2} \mathrm{O}_{2}\right.$ equivalent/L)/TAS $(\mu \mathrm{mol}$ Trolox equivalent/L) $\times 100$.

Plasma cancer antigen 125 (Ca 125) level was measured by enzyme-linked immunosorbent assay using a commercial kit (Shanghai SunRed Biological Company, Catalogue no: 201-11-0448).

\section{Statistical Analysis}

Data were analyzed using the Statistical Package for Social Sciences (SPSS Inc; Chicago, IL, USA) version 20.0. Normality of the variables was analyzed using the Shapiro-Wilk test. Numerical data were presented as mean \pm standard deviation. Intergroup differences of the numerical data were evaluated with One-Way ANOVA test. The Bonferroni test was used for the post-hoc analysis. A $p$ value of less than 0.005 was considered statistically significant.

\section{Results}

During this procedure, in each group, one rat died. The evaluation of the blood samples taken at the beginning of the procedure (1st day) showed that there were no significant differences between the groups in terms of $\mathrm{Ca}$ 125, TAS, TOS and OSI values (Table 1).

Evaluation of the blood samples taken in the $15^{\text {th }}$ day of the procedure showed that there was a significant difference in Ca 125, TOS and OSI values between sham and EMS + ALA groups and EMS group, and in TAS value between sham group and EMS group (Table 2).

Figure 1 and Table 3 show the comparisons of $\mathrm{Ca}$ 125, TAS, TOS and OSI values in the 1 st and $15^{\text {th }}$ days of the procedure. All parameters in EMS group showed statistically significant differences between the 1st and $15^{\text {th }}$ days $(p<0.05)$. There was a significant difference between Ca 125, TOS and OSI values on the 1 st day and those on the $15^{\text {th }}$ day in EMS + ALA group, but the difference was not as significant as in EMS group.

\section{Discussion}

This study investigates the effects of ALA treatment and the relationship between EMS and OS in an experimental rat EMS model. The study determined that ALA had positive effects on EMS through biochemical indicators. TOS, OSI and Ca 125 values were found to be significantly different in EMS + ALA group compared to EMS group.

EMS etiology is still not clear despite growing information. OS is the imbalance between free radicals such as reactive oxygen species (ROS) and antioxidant defense system. OS is thought to have a role in the

\begin{tabular}{|c|c|c|c|c|}
\hline & Sham $(n=10)$ & EMS $(n=10)$ & $E M S+A L A(n=10)$ & $p$ value \\
\hline Ca125 & $1.19 \pm 0.09$ & $1.22 \pm 0.07$ & $1.18 \pm 0.12$ & 0.611 \\
\hline TAS & $1.95 \pm 0.36$ & $1.73 \pm 0.40$ & $1.87 \pm 0.23$ & 0.364 \\
\hline TOS & $14.06 \pm 2.26$ & $14.39 \pm 3.24$ & $14.12 \pm 3.59$ & 0.968 \\
\hline OSI & $7.39 \pm 1.69$ & $8.42 \pm 1.48$ & $7.73 \pm 2.37$ & 0.467 \\
\hline \multicolumn{5}{|c|}{$\begin{array}{l}\text { One-Way ANOVA test. Ca } 125(\mathrm{U} / \mathrm{mL}), \text { TAS (mmol Trolox equivalent/L), TOS } \\
\text { ( } \mu \text { mol } \mathrm{H}_{2} \mathrm{O}_{2} \text { equivalent/L) and OSI (arbitrary unit). } \\
\text { EMS: Endometriosis, ALA: Alpha lipoic acid, TAS: Total antioxidant status, TOS: } \\
\text { Total plasma oxidant, OSI: Oxidative stress index, n: Number }\end{array}$} \\
\hline
\end{tabular}

\begin{tabular}{|c|c|c|c|c|}
\hline & Sham & EMS & EMS + ALA & $p$ value \\
\hline Ca 125 & $1.25 \pm 0.16$ & $1.62 \pm 0.15$ & $1.32 \pm 0.16$ & $<0.001^{a, c}$ \\
\hline TAS & $1.88 \pm 0.39$ & $1.32 \pm 0.27$ & $1.62 \pm 0.34$ & $0.005^{a}$ \\
\hline TOS & $14.59 \pm 1.61$ & $18.69 \pm 2.63$ & $15.61 \pm 3.15$ & $0.003^{a, c}$ \\
\hline OSI & $8.12 \pm 2.09$ & $13.14 \pm 2.55$ & $9.93 \pm 2.55$ & $<0.001 \mathrm{a}, \mathrm{c}$ \\
\hline \multicolumn{5}{|c|}{$\begin{array}{l}\text { One-Way ANOVA test. Post-hoc analysis Bonferroni test was applied. Ca } 125 \text { (U/ } \\
\mathrm{mL} \text { ), TAS (mmol Trolox equivalent/L), TOS }\left(\mu \mathrm{mol} \mathrm{H}_{2} \mathrm{O}_{2} \text { equivalent/L) and OSI }\right. \\
\text { (arbitrary unit). } \\
\text { aSignificantly different in sham group compared to EMS group. } \\
\text { bSignificantly different in sham group compared to EMS + ALA group. } \\
\text { cSignificantly different in EMS group compared to EMS + ALA group. } \\
\text { EMS: Endometriosis, ALA: Alpha lipoic acid, TAS: Total antioxidant status, TOS: } \\
\text { Total plasma oxidant, OSI: Oxidative stress index }\end{array}$} \\
\hline
\end{tabular}




\begin{tabular}{|c|c|c|c|c|}
\hline Groups & Parameters & Mean & SD & $\mathrm{p}$ value \\
\hline \multirow[b]{2}{*}{ Sham } & TAS(1)-TAS(2) & 0.07 & 0.66 & 0.733 \\
\hline & $\operatorname{TOS}(1)-\operatorname{TOS}(2)$ & -0.52 & 1.07 & 0.157 \\
\hline \multirow{7}{*}{ EMS } & OSI(1)-OSI(2) & -0.73 & 3.15 & 0.481 \\
\hline & Ca 125(1)-Ca 125(2) & -0.05 & 0.15 & 0.273 \\
\hline & $\operatorname{TAS}(1)-\operatorname{TAS}(2)$ & 0.41 & 0.13 & $<0.001$ \\
\hline & $\operatorname{TOS}(1)-\operatorname{TOS}(2)$ & -4.30 & 2.93 & 0.001 \\
\hline & OSI(1)-OSI(2) & -4.72 & 2.40 & $<0.001$ \\
\hline & Ca 125(1)-Ca 125(2) & -0.39 & 0,167 & $<0.001$ \\
\hline & $\operatorname{TAS}(1)-\operatorname{TAS}(2)$ & 0.24 & 0.40 & 0.089 \\
\hline \multirow{3}{*}{$E M S+A L A$} & $\operatorname{TOS}(1)-\operatorname{TOS}(2)$ & -1.48 & 1.68 & 0.021 \\
\hline & OSI(1)-OSI(2) & -2.20 & 2.79 & 0.034 \\
\hline & Ca $125(1)-$-Ca 125(2) & -0.13 & 0.15 & 0.019 \\
\hline \multicolumn{5}{|c|}{$\begin{array}{l}\text { Paired t test. Ca } 125(\mathrm{U} / \mathrm{mL}) \text {, TAS (mmol Trolox equivalent/L), TOS } \\
\text { ( } \mu \text { mol } \mathrm{H}_{2} \mathrm{O}_{2} \text { equivalent/L) and OSI (arbitrary unit). } \\
\text { (1): } 1^{\text {st }} \text { day level, }(2): 15^{\text {th }} \text { day level } \\
\text { EMS: Endometriosis, ALA: Alpha lipoic acid, TAS: Total antioxidant } \\
\text { status, TOS: Total plasma oxidant, OSI: Oxidative stress index, SD: } \\
\text { Standard deviation }\end{array}$} \\
\hline
\end{tabular}

development of EMS as in numerous diseases (20-22). ROS in oviductal fluid affects the reproductive system at various levels from ovulation to implantation. Additionally, ROS molecules may cause damage by adhering to various structures in the cell. Cellular debris in oviductal fluid and erythrocytes forms a source for OS reactions. Erythrocytes are likely to release pro-oxidant and proinflammatory factors, such as heme and iron, into the peritoneal cavity. These factors play an important role in the formation of ROS if not properly cleaned from the environment (23). On the other hand, OS increases the growth and implantation of endometrial cells in the peritoneal cavity. Thus, a vicious cycle forms between EMS and OS. Jamali et al. (9) compared eutopic and ectopic endometrial cells and found that malondialdehyde (MDA) levels increased in ectopic endometrial cells while glutathione (GSH) levels decreased. Turgut et al. (22) conducted a study with 72 women who were operated for different indications and divided the patients into groups based on EMS diagnosis. While the level of OS indicators such as copper, ceruloplasmin and TAS was high in EMS group, the TAS was significantly low. Amreen et al. (8) revealed a

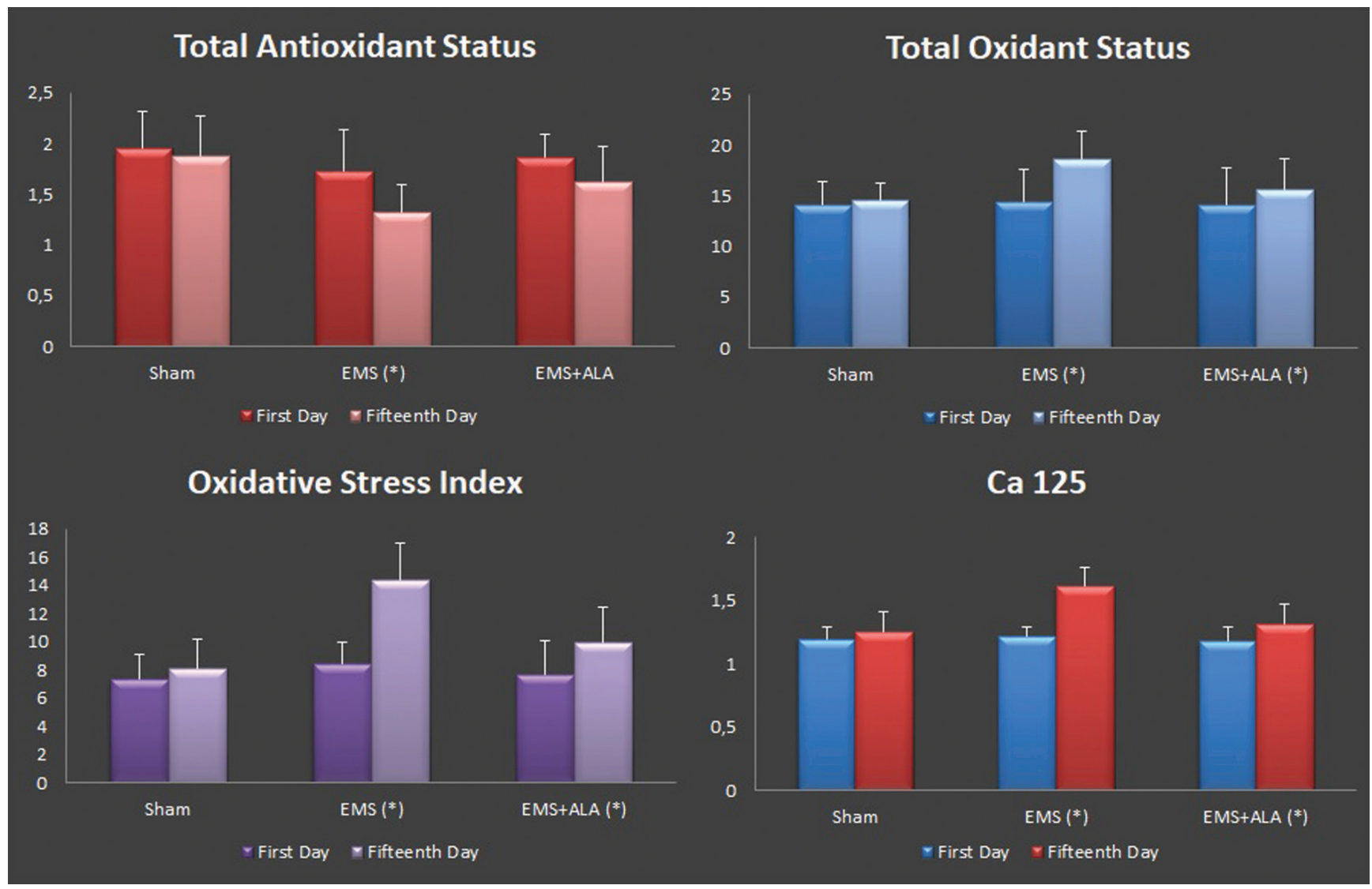

Figure 1. Comparison of the 1 st and $15^{\text {th }}$ day levels of the biochemical indicators of groups. $\left[\left(^{*}\right)\right.$ : The change of the biochemical indicator is statistically significant]

EMS: Endometriosis, ALA: Alpha lipoic acid 
relationship between OS and disease severity. The present study found a significant correlation between EMS and OS, in line with the literature.

Ca 125, an indicator in the glycoprotein structure, is used for the evaluation of ovarian masses. However, its diagnostic value is low, similar to other cancer indicators (24). Studies showed that Ca 125 increases in various malign and benign conditions such as chronic liver diseases, EMS, pelvic inflammatory disease, ovarian, endometrium and gastrointestinal tract cancers (25-29). Studies also showed that Ca 125 level which is known to increase in EMS is correlated with the stage of illness (27). Oliveira et al. (30) revealed that Ca 125 measurement made in midcycle was more effective in EMS diagnosis. In the present study, we used CA 125 level to verify EMS diagnosis and found that elevated $\mathrm{Ca} 125$ increased the probability of the diagnosis. Additionally, the study found that ALA treatment significantly decreased the Ca 125 level.

Cells try to be freed from oxidant stress with enzymatic and non-enzymatic antioxidant mechanisms. Numerous antioxidant substances have been used against OS in non-enzymatic chol $(9-12,14)$. Erten et al. (11) examined the effects of vitamin $C$ on endometriotic implants and found that vitamin $C$ suppressed the growth of endometrial implants and reduced the size of these implants. Another study found that caffeic acid may decrease EMS-related complications by reducing OS (9). Resveratrol has been used to reduce the effects of OS and similar results obtained (31). Additionally, antioxidants have been found to be effective in reducing EMS-related pain (32). ALA is a powerful antioxidant that is a cofactor for disulfide structures and is synthesized within a number of tissues including the liver (13). 20$40 \%$ of orally taken ALA get into circulation and reach to the highest plasma concentrations within 30-120 minutes (33). A study examining the effects of ALA on intestinal I/R damage determined that there was a statistically significant difference in MDA and GSH levels between ALA-treated and nontreated rats (34). Deng et al. (35) determined that ALA in myocardial I/R had a positive effect on heart functions after $\mathrm{I} / \mathrm{R}$ by reducing necrosis, apoptosis and inflammation in cardiomyocytes. As we mentioned above, there is a vicious circle between EMS and OS. We think that ALA neutralizes ROS and reduces the effects of these molecules such as inflammation, angiogenesis, adhesion and endometriotic cell differentiation. If we consider the relationship between EMS and OS, it can be said that ALA had a positive effect on EMS in our study.

\section{Study Limitations}

The limitations of this study were that EMS was evaluated with only biochemical methods, and histopathological verification was not done. Another limitation is that the verification rate of the study results in humans is low due to the fact that it was an animal study.

\section{Conclusion}

EMS is a chronic disease that tends to relapse despite various treatments. ALA with proven antioxidant effect reduces OS in EMS; thus, may positively affect the severity and stage of illness and reduce recurrence after treatment. In order to confirm our results, studies including histopathological evaluation are needed.

\section{Authorship Contributions}

Concept: T.O., M.Ç., Design: T.O., M.Ç., Data Collection or Processing: T.O., M.Ç., Analysis or Interpretation: T.O., M.Ç., Literature Search: T.O., M.Ç., Writing: T.O., M.Ç.

Conflict of Interest: No conflict of interest was declared by the authors.

Financial Disclosure: The authors declared that this study received no financial support.

\section{References}

1. Giudice LC, Kao LC. Endometriosis. Lancet (London, England) 2004;364:1789-99.

2. Kuohung $W$, Jones $G L$, Vitonis $A F$, et al. Characteristics of patients with endometriosis in the United States and the United Kingdom. Fertil Steril 2002;78:767-72.

3. Rokitansky CV. Ueber Uterusdrusen-neubildung in Uterus and Ovariul Sarcomen. Z Gesellschaft Aerzte Wien 1860;16:577.

4. Sampson JA. Peritoneal endometriosis due to the menstrual dissemination of endometrial tissue into the peritoneal cavity. Am J Obstet Gynecol 1927;14:422-69.

5. Chapron C, Marcellin L, Borghese B, Santulli P. Rethinking mechanisms, diagnosis and management of endometriosis. Nat Rev Endocrinol 2019;15:666-82.

6. Lambrinoudaki IV, Augoulea A, Christodoulakos GE, et al. Measurable serum markers of oxidative stress response in women with endometriosis. Fertil Steril 2009;91:46-50.

7. Jackson L, Schisterman E, Dey-Rao R, Browne R, Armstrong D. Oxidative stress and endometriosis. Hum Reprod 2005;20:2014-20.

8. Amreen S, Kumar P, Gupta P, Rao P. Evaluation of oxidative stress and severity of endometriosis. J Hum Reprod Sci 2019;12:40-6.

9. Jamali N, Mostafavi-Pour Z, Zal F, et al. Combination Effect of Caffeine and Caffeic Acid Treatment on the Oxidant Status of Ectopic Endometrial Cells Separated from Patients with Endometriosis. Iranian J Med Sci 2019;44:315-24.

10. Yavuz S, Aydin NE, Celik O, Yilmaz E, Ozerol E, Tanbek K. Resveratrol successfully treats experimental endometriosis through modulation of oxidative stress and lipid peroxidation. J Cancer Res Ther 2014;10:324-9. 
11. Erten OU, Ensari TA, Dilbaz B, et al. Vitamin C is effective for the prevention and regression of endometriotic implants in an experimentally induced rat model of endometriosis. Taiwanese J Obstet Gynecol 2016;55:251-7.

12. Packer L. Alpha-lipoic acid: a metabolic antioxidant which regulates NF-kappa B signal transduction and protects against oxidative injury. Drug Metab Rev 1998;30:245-75.

13. Gorąca A, Huk-Kolega H, Piechota A, Kleniewska P, Ciejka E, Skibska B. Lipoic acid-biological activity and therapeutic potential. Pharmacol Rep 2011;63:849-58.

14. Sehirli O, Sener E, Cetinel S, Yüksel M, Gedik N, Sener G. Alpha-lipoic acid protects against renal ischaemia-reperfusion injury in rats. Clin Exp Pharmacol Physiol 2008;35:249-55.

15. Cosar E, Sahin FK, Köken G, Toy H, Basarali K, Büyükbas S. The protective effect of alpha-lipoic acid in experimental ovarian ischaemia-reperfusion injury. Aust NZJ Obstet Gynaecol 2007; 47:499-503.

16. Uygur D, Aytan H, Zergeroglu S, Batioglu S. Leflunomidean immunomodulator-induces regression of endometrial explants in a rat model of endometriosis. J Soc Gynecol Investig 2006;13:378-83.

17. Erel O. A novel automated direct measurement method for total antioxidant capacity using a new generation, more stable ABTS radical cation. Clin Biochem 2004;37:277-85.

18. Erel O. A new automated colorimetric method for measuring total oxidant status. Clin Biochem 2005;38:1103-11.

19. Yanik M, Erel $O$, Kati $M$. The relationship between potency of oxidative stress and severity of depression. Acta Neuropsychiatr 2004;16:200-3.

20. Madazli R, Benian A, Aydin S, Uzun H, Tolun N. The plasma and placental levels of malondialdehyde, glutathione and superoxide dismutase in pre-eclampsia. J Obstet Gynaecol 2002;22:477-80.

21. Schisterman EF, Faraggi $D$, Browne $R$, et al. TBARS and cardiovascular disease in a population-based sample. J Cardiovasc Risk 2001;8:219-25.

22. Turgut A, Ozler A, Goruk N, Tunc S, Evliyaoglu O, Gul T. Copper, ceruloplasmin and oxidative stress in patients with advanced-stage endometriosis. Eur Rev Med Pharmacol Sci 2013;17:1472-8.

23. Defrère $S$, Van Langendonckt A, Vaesen S, et al. Iron overload enhances epithelial cell proliferation in endometriotic lesions induced in a murine model. Hum Reprod 2006;21:2810-6.

24. Carlson KJ, Skates SJ, Singer DE. Screening for ovarian cancer. Ann Int Med 1994;121:124-32.
25. Jiang T, Huang L, Zhang S. Preoperative serum CA125: a useful marker for surgical management of endometrial cancer. BMC Cancer 2015;15:396.

26. Aflatoonian A, Rahmani E, Rahsepar M. Assessing the efficacy of aspiration and ethanol injection in recurrent endometrioma before IVF cycle: A randomized Clinical Trial. Iranian J Reprod Med 2013;11:179-84.

27. Karimi-Zarchi M, Dehshiri-Zadeh N, Sekhavat L, Nosouhi F. Correlation of CA-125 serum level and clinico-pathological characteristic of patients with endometriosis. Int J Reprod Biomed 2016;14:713-8.

28. Huo YR, Huang Y, Liauw W, Zhao J, Morris DL. Prognostic value of carcinoembryonic antigen (CEA), AFP, CA19-9 and CA125 for patients with colorectal cancer with peritoneal carcinomatosis treated by cytoreductive surgery and intraperitoneal chemotherapy. Anticancer Res 2016;36:10419.

29. Park ST, Lee SW, Kim MJ, Kang YM, Moon HM, Rhim CC. Clinical characteristics of genital chlamydia infection in pelvic inflammatory disease. BMC Women's Health 2017;17:5.

30. Oliveira MAP, Raymundo TS, Soares LC, Pereira TRD, Demôro AVE. How to use CA-125 more effectively in the diagnosis of deep endometriosis. Biomed Res Int 2017;2017:9857196.

31. Ozcan Cenksoy P, Oktem M, Erdem O, et al. A potential novel treatment strategy: inhibition of angiogenesis and inflammation by resveratrol for regression of endometriosis in an experimental rat model. Gynecol Endocrinol 2015;31:21924.

32. Santanam N, Kavtaradze N, Murphy A, Dominguez C, Parthasarathy S. Antioxidant supplementation reduces endometriosis-related pelvic pain in humans. Transl Res 2013;161:189-95.

33. Petersen Shay K, Moreau RF, Smith EJ, Hagen TM. Is $\alpha$-lipoic acid a scavenger of reactive oxygen species in vivo? Evidence for its initiation of stress signaling pathways that promote endogenous antioxidant capacity. IUBMB lif 2008;60:362-7.

34. Tunc T, Öter S, Güven A, et al. Protective effect of sulfhydrylcontaining antioxidants against ischemia/reperfusion injury of prepubertal rat intestine. J Gastroenterol Hepatol 2009;24:681-7.

35. Deng C, Sun Z, Tong G, et al. $\alpha$-Lipoic acid reduces infarct size and preserves cardiac function in rat myocardial ischemia/ reperfusion injury through activation of PI3K/Akt/Nrf2 pathway. PloS One 2013;8:e58371. 